\title{
Authentication of a traditional game meat sausage (Alheira) by species-specific PCR assays to detect hare, rabbit, red deer, pork and
} cow meats

\author{
Joana S. Amaral ${ }^{\mathrm{a}, \mathrm{b}, *}$, Cristina G. Santos ${ }^{\mathrm{a}, \mathrm{b}}$, Vitor S. Melo ${ }^{\mathrm{a}, \mathrm{b}}$, M. Beatriz P.P. Oliveira $^{\mathrm{a}}$, Isabel Mafra ${ }^{\mathrm{a}, * *}$ \\ a REQUIMTE, Departamento de Ciências Químicas, Faculdade de Farmácia, Universidade do Porto, Rua de Jorge Viterbo Ferreira, 228, 4050-313 Porto, Portugal \\ b Instituto Politécnico de, Campus de Sta. Apolónia, 5301-857 Bragança, Portugal
}

\section{A R T I C L E I N F O}

\section{Article history:}

Received 9 August 2013

Received in revised form 9 October 2013

Accepted 3 November 2013

Available online 9 November 2013

\section{Keywords:}

Alheira

Game meat

Species identification

Authenticity

PCR

Meat products

\begin{abstract}
A B S T R A C T
Alheira is a traditional meat product that is typical from the Northeast region of Portugal and much appreciated. It is a sort of sausage produced industrially or by small artisanal producers, having wheat bread and meats as main ingredients. Game meat Alheira (Alheira de caça) is considered one of the most attractive products since it should include different game meats. The aim of the present work was to identify the species of origin of meats added to game meat Alheira samples to verify their compliance with labelling. Species-specific PCR assays targeting mitochondrial genes of rabbit, hare, red deer, cow and pork were optimised and applied to industrial and artisanal samples. The assays revealed adequate specificity for each of the targeted species, with sensitivities of $0.01-0.1 \%$. Results of the evaluation of 18 commercial samples identified several inconsistencies with labelling, namely the absence of declared game species (red deer, hare and rabbit) in ten samples and the presence of undeclared cow species in nine of the analysed samples. These findings indicate the occurrence of misleading labelling, suggesting the adulteration by substitution of game meats by cow meat to reduce production costs and the need to protect and valorise this kind of traditional food product.
\end{abstract}

(C) 2013 Elsevier Ltd. All rights reserved

\section{Introduction}

Meat species identification in processed food products has been gaining an increasing interest mainly due to public health, economic and legal concerns, but also due to religious reasons. Food authenticity assessment of processed meat products encompasses several issues, including the detection of fraudulent substitution of higher commercial valued meat species by less expensive ones, the presence of undeclared species, the substitution of animal by vegetable proteins and fraudulent mislabelling (Ballin, Vogensen, \& Karlsson, 2009). In particular, meat and meat products with higher market value are very prone to adulterations. In the last years, game meat consumption has been increasing due to several motivations, such as its particular and more intense taste and flavour, its healthier composition (with lower fat and cholesterol contents) and the attraction of some people for the new and exotic food experiences (Fajardo et al., 2010). For these reasons, game meats, generally considered as delicacy products, command higher prices compared to other meats, thus being susceptible targets for frauds. Game meat is still used in traditional recipes, but nowadays, new and

\footnotetext{
* Correspondence to: J.S. Amaral, REQUIMTE, Departamento de Ciências Químicas, Faculdade de Farmácia, Universidade do Porto, Rua de Jorge Viterbo Ferreira, 228, 4050313 Porto, Portugal. Tel.: + 351220428640.

** Corresponding author. Tel.: + 351220428640.

E-mail addresses: jamaral@ipb.pt (J.S. Amaral), isabel.mafra@ff.up.pt (I. Mafra).
}

reinvented gastronomic delicacies are being proposed by the meat industry, with "game meat Alheiras" being one of such cases in Portugal.

Alheira is a traditional, smoked, naturally-fermented meat product typical from the Northeast region of Portugal (Trás-os-Montes) that is very appreciated in the whole country. Its origin goes back to the end of the fifteenth century, being related to the presence of Jewish communities in this region. According to history, to avoid identification of Jewish population by the Inquisition owing to their different eating habits, they developed a type of sausage similar in shape to those that were part of the regional Christian cuisine, but which was stuffed with chicken and flour instead of pork. The recipe eventually become popular among Christians and nowadays they are produced from a combination of pork meat, pork lard, poultry, wheat bread and olive oil mixed with salt, garlic and spices.

The manufacture of traditional meat products, and in particular of Alheiras, is a long-established practice in the Northeast of Portugal, with several industries and small artisanal producers, called Cozinhas Regionais de Fumeiro, producing this well-defined composition meat products (Ramalhosa, Magalhães, \& Pereira, 2012). In the last years, different and innovative types of Alheira have also become available, from which game meat Alheira (Alheira de caça) is considered one of the most attractive products. Due to their composition, that totally or partially includes different types of game meat, such as red deer, hare, wild rabbit, wild boar, pheasant and partridge, its price is significantly higher compared to that of the most common sorts of Alheira produced 
with pork and poultry meats. Since this product command higher prices and game meat can be, in some cases, restricted to hunting seasons and animal availability, game meat Alheira is a product prone to fraudulent meat substitutions. Therefore, to be able to authenticate this type of processed meat product, analytical methodologies are required to specifically and unequivocally assess meat species identification.

Recently, DNA-based methods have been considered as essential tools for species identification in animal products and foodstuffs, and its use is becoming widespread for this purpose. Compared to proteinbased techniques, they present several advantages such as the ubiquity of nucleic acids in every type of cells and its higher stability when compared to proteins. Among DNA-based methods, polymerase chain reaction (PCR) is the most well developed molecular technique up to now because of its simplicity, fastness, specificity and sensitivity, enabling the identification of species of origin even in complex and processed foods (Bottero \& Dalmasso, 2011; Mafra, Ferreira, \& Oliveira, 2008). A primary aspect for successfully detecting a species by PCR is the choice of adequate genetic markers for assay development. Both nuclear and mitochondrial genes have been broadly targeted for the identification of game and domestic meat species (Fajardo et al., 2010). The use of mitochondrial DNA (mtDNA) sequences offers a series of advantages over other genetic markers like cell nucleus DNA. The fact that mtDNA is several fold more abundant than that of nuclear genome facilitates PCR amplification, contributing to improve the assay sensitivity (Girish et al., 2005; Rodríguez, García, González, Hernández, \& Martín, 2005). Among the mitochondrial genes, cytochrome $b(c y t b)$ is the most studied gene for phylogeny and the most used for molecular identification studies (Teletchea, Maudet, \& Hanni, 2005).

The vast majority of PCR applications for meat identification has been focused on domestic animal species like cattle, sheep, goat, domestic pig, turkey or chicken (Ballin et al., 2009; Colgan et al., 2001; Ghovvati, Nassiri, Mirhoseini, Moussavi, \& Javadmanesh, 2009; Girish et al., 2005; Hernandez-Chavez, Gonzalez-Cordova, RodriguezRamirez, \& Vallejo-Cordoba, 2011; Martín et al., 2007; Martín et al., 2009b; Matsunaga et al., 1999; Soares, Amaral, Mafra, \& Oliveira, 2010; Stamoulis, Stamatis, Sarafidou, \& Mamuris, 2010), being considerably higher than the reports dealing with game meat authentication (Fajardo et al., 2010; Rojas et al., 2009, 2010; Rojas et al., 2011). Other works aiming at identifying game species only deal with method development without further application to processed foods (Brodmann, Nicholas, Schaltenbrand, \& Ilg, 2001; Fajardo et al., 2007, 2008a, 2008b; Fajardo et al., 2009; La Neve, Civera, Mucci, \& Bottero, 2008; Martín et al., 2009a; Santos et al., 2012). PCR using species-specific primers is one of the most used approaches since it offers simplicity, specificity and high sensitivity for meat authentication studies. In the particular case of highly processed and mixed-species food matrices, PCR using specific primers targeting short DNA fragments represents a powerful tool for species identification (Fajardo et al., 2010; Mafra, Ferreira, \& Oliveira, 2008).

In this work, species-specific PCR assays were optimised and evaluated for their suitability for meat origin identification from game animals (deer, hare and wild rabbit) and also from domestic animals (pork and cow) to assess the authenticity of game meat Alheiras. Several samples of commercial game meat Alheiras were evaluated to verify labelling compliance and the existence of fraudulent practices. This approach can contribute to reinforce consumer's trust on traditional meat products and avoid unfair competition among producers.

\section{Materials and methods}

\subsection{Samples}

Samples of pork (Sus scrofa) and cow (Bos taurus) muscles and samples of authentic game meat, namely hare (Lepus sp.), red deer (Cervus elaphus), wild rabbit (Oryctolagus cuniculus) and wild boar (Sus scrofa scrofa) were acquired from the retail market and local hunters. In the case of hare and wild rabbit, the samples consisted of the entire animal, not eviscerated, with hair, to confirm their authenticity. For each species, reference binary mixtures containing known proportions of the considered meat $(0.01 \%, 0.1 \%, 0.5 \%, 1 \%, 2.5 \%, 5 \%$, $10 \%$ and $20 \%(\mathrm{w} / \mathrm{w}))$ in pork meat to a final weight of $100 \mathrm{~g}$ were prepared.

A total of 18 different commercial samples of game meat Alheira sausages acquired in local markets and directly from local producers were evaluated in the present study. Each sample was cut in halves and divided into two groups, one containing the casing and the other subjected to careful casing removal. All samples, including authentic meats, reference binary mixtures and commercial Alheira sausages were separately minced in a blender, using different material and different blender containers previously treated with DNA decontaminator solution to avoid contaminations.

A wide range of non-target animal species was included in the study for specificity assays, namely partridge (Alectoris spp.), red legged partridge (Alectoris rufa), pheasant (Phasianus colchicus), quail (Coturnix coturnix), turkey (Meleagris gallopavo), chicken (Gallus gallus), duck (Anas platyrhynchos), ostrich (Struthio camelus), sheep (Ovis aries) and goat (Capra hircus). Other ingredients that can also be used in the production of Alheira sausages were also included in the study for specificity assays, namely wheat bread, rye bread, garlic, parsley, paprika, onions, white pepper, laurel, chilli, corn and soybean.

All samples were extracted immediately or stored at $-20{ }^{\circ} \mathrm{C}$ to prevent enzymatic DNA degradation.

\subsection{DNA extraction}

DNA was extracted using the Wizard method with minor modifications as described by Mafra, Silva, Moreira, Ferreira da Silva, and Oliveira (2008). Briefly, $100 \mathrm{mg}$ of grounded and homogenised sample was transferred to a $2 \mathrm{~mL}$ sterile reaction tube followed by the addition of $860 \mu \mathrm{L}$ of TNE extraction buffer $\left(10 \mathrm{mmol} \mathrm{L}^{-1}\right.$ Tris, $150 \mathrm{mmol} \mathrm{L}^{-1}$ $\mathrm{NaCl}, 2$ mmol L ${ }^{-1}$ EDTA, $1 \% \mathrm{SDS}$ ), $100 \mu \mathrm{L}$ of $5 \mathrm{~mol} \mathrm{~L}^{-1}$ guanidine hydrochloride solution and $40 \mu \mathrm{L}$ of proteinase K solution $\left(20 \mathrm{mg} \mathrm{mL}^{-1}\right)$. After the incubation at $60{ }^{\circ} \mathrm{C}$ for $3 \mathrm{~h}$, with occasional stirring, the suspension was centrifuged ( $15 \mathrm{~min}, 18,514 \mathrm{~g}$ ) and $500 \mu \mathrm{L}$ of the supernatant were mixed with $1 \mathrm{~mL}$ of Wizard DNA purification resin (Promega, Madison, WI, USA). The mixture was eluted through a column and the resin was washed with $2 \mathrm{~mL}$ of isopropanol solution $(80 \%, \mathrm{v} / \mathrm{v})$. After drying the column, the DNA was eluted by centrifugation ( $1 \mathrm{~min}, 10,000 \mathrm{~g}$ ) with $100 \mu \mathrm{L}$ of Tris-EDTA buffer ( $10 \mathrm{mmol} \mathrm{L}^{-1}$ Tris, $1 \mathrm{mmol} \mathrm{L}^{-1}$ EDTA) at $70{ }^{\circ} \mathrm{C}$ to a new reaction tube. The extractions were performed in duplicate assays for each binary mixture and sample.

\subsection{DNA quantification and purity}

The quality of extracted DNA was analysed by electrophoresis in a $1.0 \%$ agarose gel containing Gel Red $1 \times$ (Biotium, Hayward, CA, USA) for staining and carried out in TAE buffer $\left(40 \mathrm{mmol} \mathrm{L}^{-1}\right.$ Tris-acetate, $1 \mathrm{mmol} \mathrm{L}^{-1}$ EDTA) for $40 \mathrm{~min}$ at $120 \mathrm{~V}$. The agarose gel was visualised under UV light and a digital image was obtained using a Kodak Digital Science ${ }^{\mathrm{TM}}$ DC120 (Rochester, NY, USA).

The DNA was quantified by spectrophotometry using a Shimadzu UV-1800 spectrophotometer (Shimadzu Corporation, Kyoto, Japan). The DNA concentration was determined by UV absorbance at $260 \mathrm{~nm}$ ( 1 absorbance unit corresponds to $50 \mu \mathrm{mL}^{-1}$ of dsDNA). The purity of the extracted DNA was determined by the ratio of the absorbance at 260 and $280 \mathrm{~nm}$.

\subsection{Target gene selection and oligonucleotide primers}

The species-specific oligonucleotide primers used in this work targeted mitochondrial genes of hare, rabbit, red deer and pork, previously reported in the literature (Table 1 ). For the identification of 
Table 1

Oligonucleotide primers.

\begin{tabular}{|c|c|c|c|c|c|}
\hline Species & Primer & Target gene & $\begin{array}{l}\text { Sequence } \\
\left(5^{\prime} \rightarrow 3^{\prime}\right)\end{array}$ & $\begin{array}{l}\text { Amplicon } \\
\text { (bp) }\end{array}$ & Reference \\
\hline Sus scrofa & Pork-R & $c y t b$ & $\begin{array}{l}\text { ATG AAA CAT } \\
\text { TGG AGT AGT } \\
\text { CCT ACT ATT } \\
\text { TAC A } \\
\text { CTA CGA GGT } \\
\text { CTG TTC CGA } \\
\text { TAT AAG G }\end{array}$ & 149 & $\begin{array}{l}\text { Dooley, Paine, } \\
\text { Garrett, and } \\
\text { Brown (2004) }\end{array}$ \\
\hline $\begin{array}{l}\text { Oryctolagus } \\
\text { cuniculus }\end{array}$ & $\begin{array}{l}\text { 12SpRab-F } \\
\text { 12SpRab-R }\end{array}$ & rRNA $12 \mathrm{~S}$ & $\begin{array}{l}\text { CAA AAG TAA } \\
\text { GCT CAA TTA } \\
\text { CCA CCG TA } \\
\text { ATA AGG GCT } \\
\text { TTC GTA TAT } \\
\text { TCG GAA }\end{array}$ & 110 & $\begin{array}{l}\text { Martín et al. } \\
\text { (2009a) }\end{array}$ \\
\hline Lepus spp. & Lep-F & $c y t b$ & $\begin{array}{l}\text { ATA CAT GTA } \\
\text { GGC CGT } \\
\text { GGA } \\
\text { ATC TAC } \\
\text { TTT GTC CTC } \\
\text { ATG GGA } \\
\text { GGA CGT A }\end{array}$ & 127 & $\begin{array}{l}\text { Santos et al. } \\
\text { (2012) }\end{array}$ \\
\hline $\begin{array}{l}\text { Cervus } \\
\text { elaphus }\end{array}$ & 12SCEQ-R & rRNA $12 \mathrm{~S}$ & $\begin{array}{l}\text { CAA AAA CAT } \\
\text { ATA ACG AAA } \\
\text { GTA ACT TTC } \\
\text { CGA CC } \\
\text { AGT ACT CTG } \\
\text { GCG AAT AGT } \\
\text { TTT GTC TGC } \\
\text { A }\end{array}$ & 134 & $\begin{array}{l}\text { Fajardo et al. } \\
\text { (2008a) }\end{array}$ \\
\hline Bos taurus & Bos-F & $c y t b$ & $\begin{array}{l}\text { CTG CCG AGA } \\
\text { CGT GAA CTA } \\
\text { CG } \\
\text { AAG CCT CGT } \\
\text { CCT ACG TGC } \\
\text { ATA }\end{array}$ & 99 & This work ${ }^{\mathrm{a}}$ \\
\hline Eukaryotic & $\begin{array}{l}\text { 18SEU-F } \\
\text { 18SEU-R }\end{array}$ & $18 \mathrm{~S}$ rRNA & $\begin{array}{l}\text { TCT GCC CTA } \\
\text { TCA ACT TTC } \\
\text { GAT GG } \\
\text { TAA TTT GCG } \\
\text { CGC CTG CTG }\end{array}$ & 140 & $\begin{array}{l}\text { Fajardo et al. } \\
\text { (2008a) }\end{array}$ \\
\hline
\end{tabular}

a Genbank accession number D34635.

cow meat, new primers were designed on the basis of the mitochondrial cytb gene sequence from various animal and plant species available in the NCBI (National Center for Biotechnology Information) Genbank database. The specific primers were designed using the software Primer3 output designing tool (http://frodo.wi.mit.edu/primer3/). The nucleotide sequence was submitted to a basic local alignment search tool BLAST (http://blast.ncbi.nlm.nih.gov/Blast.cgi), which identifies regions of local similarity among homologue sequences of different species and calculates the statistical significance of the matches (Altschul, Gish, Miller, Myers, \& Lipman, 1990). Primer specificity was assessed using the Primer-BLAST tool that allows revealing homologies in relation to all sequences available in the database (Genbank).

To assess amplifiability of DNA extracts, universal primers targeting a conserved 18S rRNA gene fragment in all eukaryotic cells were used (Table 1). The primers were synthesised by Eurofins MWG Operon (Ebersberg, Germany).

\subsection{Species-specific PCR amplification}

The PCR assays were performed in a total reaction volume of $25 \mu \mathrm{L}$ containing $2 \mu \mathrm{L}$ of DNA extract ( $20 \mathrm{ng}$ for meats and $100 \mathrm{ng}$ for samples and other tested food ingredients), $67 \mathrm{mmol} \mathrm{L}^{-1}$ Tris- $\mathrm{HCl}$ ( $\mathrm{pH} \mathrm{8.8),}$ $16 \mathrm{mmol} \mathrm{L}^{-1}\left(\mathrm{NH}_{4}\right)_{2} \mathrm{SO}_{4}, 0.01 \%$ Tween $20,0.2 \mathrm{mmol} \mathrm{L}^{-1}$ of each dNTP (Bioron, Ludwigshafen, Germany), $400 \mathrm{nmol} \mathrm{L}^{-1}$ of each primer for the target species or $600 \mathrm{nmol} \mathrm{L}^{-1}$ for eukaryotic sequences (Table 1), $1.5 \mathrm{mmol} \mathrm{L}^{-1}$ of $\mathrm{MgCl}_{2}$ for pork and cow species and $2.5 \mathrm{mmol} \mathrm{L}^{-1}$ for the others, and $1 \mathrm{U}$ of SuperHot Taq DNA polymerase
(Genaxxon Bioscience GmbH, Ulm, Germany). The reactions were performed in a thermal cycler MJ Mini (Bio-Rad Laboratories, Hercules, CA, USA) using the following programmes: (i) initial denaturation at $94{ }^{\circ} \mathrm{C}$ for $5 \mathrm{~min}$; (ii) 32 cycles (for pork, rabbit and cow DNA) or 35 cycles (for hare and eukaryotic DNA) or 38 cycles (for red deer DNA) at $94{ }^{\circ} \mathrm{C}$ for $30 \mathrm{~s}, 60{ }^{\circ} \mathrm{C}$ (except for cow and hare $65{ }^{\circ} \mathrm{C}$ ) for $30 \mathrm{~s}$ and $72{ }^{\circ} \mathrm{C}$ for $30 \mathrm{~s}$; (iii) and a final extension at $72{ }^{\circ} \mathrm{C}$ for $5 \mathrm{~min}$.

The amplified fragments were analysed by electrophoresis in a $2.0 \%$ agarose gel containing Gel Red $1 \times$ (Biotium, Hayward, CA, USA) for staining and carried out in TAE buffer $\left(40 \mathrm{mmol} \mathrm{L}^{-1}\right.$ Tris-acetate, $1 \mathrm{mmol} \mathrm{L}{ }^{-1}$ EDTA) for $60 \mathrm{~min}$ at $120 \mathrm{~V}$. The agarose gel was visualised under UV light and a digital image was obtained using a Kodak Digital Science $^{\mathrm{TM}}$ DC120 (Rochester, NY, USA). Each extract was amplified at least in duplicate assays.

\section{Results and discussion}

\subsection{Analysis of extracted DNA}

The quality of DNA extracts was examined by agarose gel electrophoresis to check for DNA integrity (data not shown). As expected, variations of DNA fragment length were observed depending on the material under examination: raw meat samples showed, in general, intense smears of short and long DNA fragments, ranging from 2000 to 10,000 bp, while DNA from Alheira samples and some tested food ingredients (such as bread and some spices) was visibly more degraded, showing sheared DNA fragments of shorter length.

The purity of the DNA extracts was generally high, ranging from 1.6 to 1.8 for most reference binary meat mixtures. A higher variability of this ratio was observed for the Alheira samples (1.5-2.2) and for most the ingredients used in its productions such as bread, garlic, and spices (1.4-2.0). The DNA yields ranged from 81 to $484 \mathrm{ng} \mu \mathrm{L}^{-1}$ for samples, from 62 to $954 \mathrm{ng} \mu \mathrm{L}^{-1}$ for food ingredients and from 179 to $981 \mathrm{ng} \mu \mathrm{L}^{-1}$ for the different meat species.

The high purity and yield of DNA extracts obtained from the different sources of animal and plant foods indicate the appropriateness of the chosen Wizard method, as previously demonstrated (Mafra, Silva, Moreira, Ferreira da Silva, \& Oliveira, 2008; Santos et al., 2012; Soares et al., 2010).

\subsection{Specificity and sensitivity of the species-specific PCR assays}

In this work, the specific identification of cow was based on the design of new primers (Bos-F/Bos-R) to amplify small DNA sequences of cytb gene ( $99 \mathrm{bp}$ ) as an adequate approach to test processed foods. Since Alheira sausages are fermented and smoked meat products, where DNA can be degraded, it is particularly advised to detect short sequences to enable amplification of fragmented DNA. The in silico analysis confirmed the specificity of the designed primers for the selected B. taurus sequence with $100 \%$ identity.

To further assess specificity of the designed primers for B. taurus, as well as the other tested species, each set of primers was assayed by PCR amplification against other animal species commonly used as food, including game and domestic animal meats (DNA extracts from wild boar, duck, partridge, quail, pheasant, chicken, turkey, ostrich, goat and sheep meats) and ingredients generally used in the manufacture of Alheira (DNA extracted from wheat bread, rye bread, garlic, parsley, paprika, onions, white pepper, laurel, chilli, corn and soybean). The results clearly indicated that the primers were only able to produce the expected fragments when the corresponding DNA for which they were designed was present, demonstrating their specificity (data not shown). To confirm that all extracts contained amplifiable DNA, they were submitted to PCR amplification using the universal primers (18SEU-F/18SEU-R) to target the nuclear 18S rRNA gene for eukaryotic DNA, which produced positive amplifications with all extracts (data not shown). 


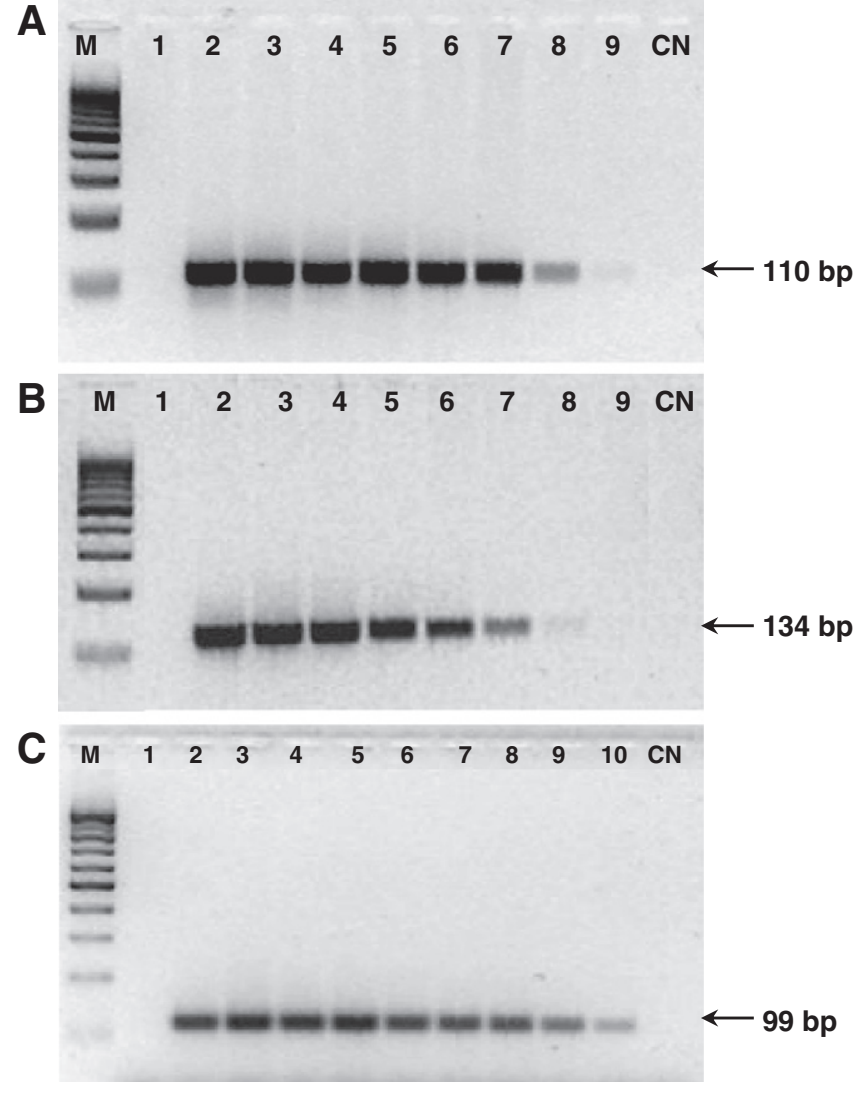

Fig. 1. Agarose gel electrophoresis of PCR products of binary reference mixtures of rabbit meat targeting rRNA $12 \mathrm{~S}$ gene (A), red deer meat targeting rRNA 12S gene (B) and cow meat targeting cytb gene $(C)$ in pork meat. Legend: $M, 100$ bp DNA ladder (Bioron, Ludwigshafen, Germany); $C N$, negative control; Lane 1, pork; Lanes $2-9,20 \%, 10 \%, 5 \%$, $2.5 \%, 1 \%, 0.5 \%, 0.1 \%, 0.01 \%$ of rabbit (A) or red deer (B); Lanes $2-10,100 \%, 20 \%, 10 \%, 5 \%$, $2.5 \%, 1 \%, 0.5 \%, 0.1 \%, 0.01 \%$ of cow meat (C).

For each species under evaluation, binary model mixtures were prepared containing known amounts of rabbit, red deer or cow meat in pork meat. In the case of pork species, the mixtures were formerly prepared by adding known amounts of pork meat to poultry meat
(Soares et al., 2010). Binary mixtures containing hare meat in pork meat were also previously prepared by Santos et al. (2012). The DNA extracts obtained from reference binary mixtures were used to optimise the amplification conditions of each species-specific PCR assay. The optimised PCR conditions allowed achieving a sensitivity of $0.01 \%$ for rabbit, cow (Fig. 1A and C) and hare (Santos et al., 2012), and of $0.1 \%$ for red deer (Fig. 1B) and pork (Soares et al., 2010).

\subsection{Application of species-specific PCR assays to game meat Alheira samples}

The optimised PCR conditions for each species under evaluation were then applied to the commercial samples of game meat Alheiras to identify meat species and to verify the compliance with the labelled statements (Fig. 2 and Table 2). As presented in Table 2, among the evaluated samples, some did not declare any of the species used in their preparation, being acquired from small artisanal producers as game meat products (samples $8,9,11$ and 12 ), one referred $10 \%$ of game meat (sample 6) declaring also other domestic meat species, while the other thirteen samples clearly specified the meat species used in their production. From the ten samples that declared the presence of rabbit/wild rabbit, only four were positive for rabbit DNA (Fig. 2A, Table 2), showing the incorrect labelling of samples 1-3 and 13-15 for this species. In the five samples allegedly containing game meat, no rabbit DNA was detected. Regarding hare meat, only one game meat Alheira declared its presence as an ingredient, but all the evaluated samples were negative for the presence of hare DNA, thus showing the mislabelling of sample 14 and the absence of this meat in the five game meat products (Fig. 2B, Table 2). In what concerns red deer, four samples out of seven labelled as containing this meat were positive to red deer DNA (Fig. 2C, Table 2). Red deer was also detected in one of the five samples acquired as game meat Alheira sausages. In this case (sample 12), the presence of red deer justifies the commercialisation of the product as a game meat Alheira. Unexpectedly, the results showed the presence of red deer DNA in sample 14, which did not refer it on the label (Fig. 2C). In the particular case of sample 14 that refers the presence of rabbit and hare meats, none of them were detected.

In this work, the presence of pork and cow meats was also evaluated since pork meat and/or lard are frequently added to this kind of product, while cow meat is suspected to be a substitute of game meat. From the thirteen labelled samples, only sample 6 declared the addition of cow meat as an ingredient (Table 2). Nevertheless, the results show that

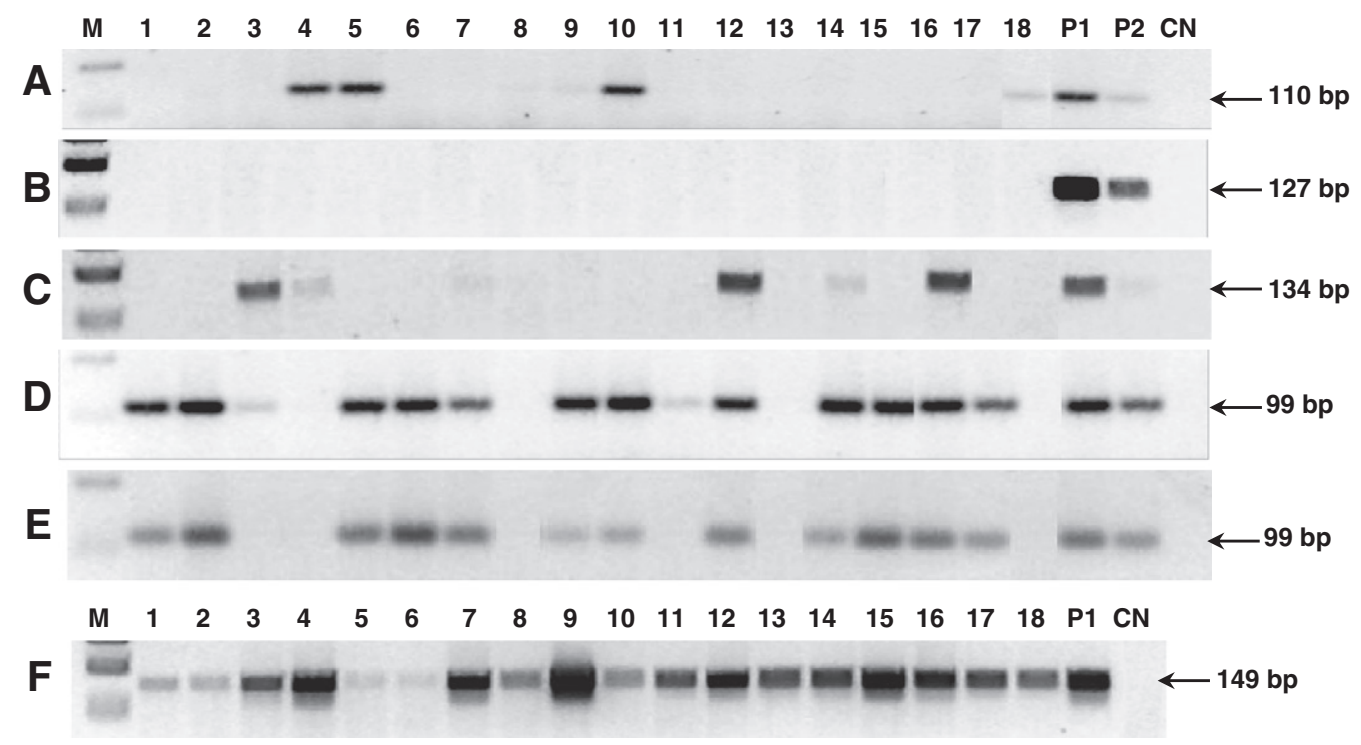

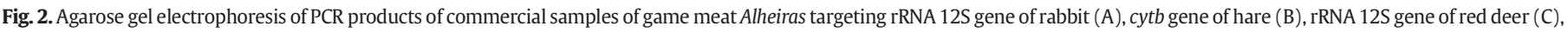

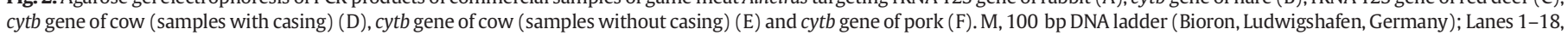
commercial samples of game meat Alheiras, Lanes P1 and P2, positive controls, corresponding to $1 \%$ and $0.1 \%$, respectively, of each targeted species; CN, negative control. 
Table 2

Summarised results of species-specific PCR to assess compliance with labelling of samples of game meat Alheiras.

\begin{tabular}{|c|c|c|c|c|c|c|c|c|c|c|}
\hline \multirow[t]{2}{*}{ Sample } & \multicolumn{2}{|l|}{ Rabbit } & \multicolumn{2}{|l|}{ Hare } & \multicolumn{2}{|c|}{ Red deer } & \multicolumn{2}{|l|}{ Cow } & \multicolumn{2}{|l|}{ Pork } \\
\hline & Label & PCR & Label & PCR & Label & PCR & Label & PCR & Label & PCR \\
\hline 1 & $\mathrm{X}$ & - & & - & & - & & + & $\mathrm{X}$ & + \\
\hline 2 & $X$ & - & & - & $X$ & - & & + & $X$ & + \\
\hline 3 & $X$ & - & & - & $X$ & + & & $+1-^{\mathrm{b}}$ & $X$ & + \\
\hline 4 & $\mathrm{X}$ & + & & - & $\mathrm{X}$ & + & & - & $X^{c}$ & + \\
\hline 5 & $X$ & + & & - & & - & & + & $X$ & + \\
\hline 6 & $\mathrm{G}^{\mathrm{a}}$ & - & G & - & G & - & $\mathrm{X}$ & + & $\mathrm{X}$ & + \\
\hline 7 & & - & & - & $\mathrm{X}$ & + & & + & $X^{c}$ & + \\
\hline 8 & G & - & G & - & G & - & & - & G & + \\
\hline 9 & G & - & G & - & G & - & & + & G & + \\
\hline 10 & & - & & - & & - & & + & $\mathrm{X}$ & + \\
\hline 11 & G & - & G & - & G & - & & $+1-^{\mathrm{b}}$ & G & + \\
\hline 12 & G & - & G & - & G & + & & + & G & + \\
\hline 13 & $X$ & - & & - & $\mathrm{X}$ & - & & - & $\mathrm{X}^{\mathrm{c}}$ & + \\
\hline 14 & $\mathrm{X}$ & - & $\mathrm{X}$ & - & & + & & + & $X^{c, d}$ & + \\
\hline 15 & $\mathrm{X}$ & - & & - & & - & & + & $\mathrm{X}$ & + \\
\hline 16 & & - & & - & $\mathrm{X}$ & + & & + & $X^{c}$ & + \\
\hline 17 & & - & & - & $\mathrm{X}$ & - & & + & $X^{c}$ & + \\
\hline 18 & $X$ & + & & - & & - & & - & $X$ & + \\
\hline
\end{tabular}

${ }^{\text {a }} \mathrm{G}$, acquired as game meat Alheira without specifying meat species.

b Positive amplification with sausage casing and negative without casing.

c Pork meat and/or wild pork meat.

d Pork lard.

cow DNA was detected in other nine samples that did not mention its presence on the label (Fig. 2D). Considering that the sausage casing can be of cattle origin, as referred in Material and methods section, the samples were analysed separately with and without casing for amplification of cow DNA. The difference between samples amplified with casing (Fig. 2D) and without casing (Fig. 2E) was noted in the disappearance of bands in lanes 3 and 11, suggesting that in these particular samples the presence of cow DNA was from the casing and not from meat. All the other PCR products had strong similar intensities regardless of the presence of sausage casing, indicating the undeclared addition of cow meat to nine samples $(1,2,5,7,10,14-17)$. Furthermore, samples 9 and 11 , acquired as game meat products, should not have cow meat in their composition. The addition of cow meat to most of samples suggests the fraudulent substitution of game meat, usually dark meats, by cow meat since other possible low cost substitutes, such as poultry and pork meat, could be easily identified by the consumers because of the lighter colour intensity. This statement can be supported analysing the overall results of samples 2 and 13, for instance, in which the former declared rabbit and red deer meats, containing cow meat instead, and the latter declared rabbit and hare meats, containing also unlabelled cow meat.

In relation to pork meat, all labelled samples indicated its presence, with the exception of sample 13 that referred the presence of wild pork meat and animal fat as ingredients (Table 2). As expected, PCR results show that all the eighteen samples were positive to pork DNA (Fig. 2F). To differentiate pork from wild pork, other intraspecific marker(s) needed to be exploited to be further applied in the authentication of such complex and processed food product.

\section{Conclusions}

The different species-specific PCR assays used in this work proved to be highly specific and sensitive, reaching relative levels of detection of $0.01 \%$ for rabbit, cow and hare, and of $0.1 \%$ for red deer and pork meats. The proposed methodologies were successfully applied to 18 commercial samples of game meat Alheira sausages, allowing the detection of several inconsistencies with labelling, namely the absence of declared game species (red deer, hare and rabbit) in ten samples and the presence of undeclared cow species in half the analysed samples. The obtained results indicate the occurrence of misleading labelling of game meat Alheira sausages, suggesting the fraudulent substitution of game meats by cow meat for reduction of productions costs. This work highlights the need for future work to verify the compliance with labelling regarding other game meat species such as pheasant and partridge. Since Alheira is considered a very appreciated and traditional meat product that should be valorised and protected, inspection programmes should be effectively put in practice to assess authenticity and avoid the occurrence of mislabelling situations, enforcing regulation in the meat sector industry.

\section{Acknowledgements}

The authors acknowledge the financial support of the University of Porto/Santander Totta "Projectos pluridisciplinares 2010" and the Fundação para a Ciência e a Tecnologia (FCT) through grant no. PEst-C/EQB/LA0006/2013.

\section{References}

Altschul, S. F., Gish, W., Miller, W., Myers, E. W., \& Lipman, D. J. (1990). Basic local alignment search tool. Journal of Molecular Biology, 215, 403-410.

Ballin, N. Z., Vogensen, F. K., \& Karlsson, A. H. (2009). Species determination - Can we detect and quantify meat adulteration? Meat Science, 83, 165-174.

Bottero, M. T., \& Dalmasso, A. (2011). Animal species identification in food products: Evolution of biomolecular methods. The Veterinary Journal, 190, 34-38.

Brodmann, P. D., Nicholas, G., Schaltenbrand, P., \& Ilg, E. C. (2001). Identifying unknown game species: Experience with nucleotide sequencing of the mitochondrial cytochrome b gene and a subsequent basic local alignment search tool search. European Food Research Technology, 212, 491-496.

Colgan, S., O'Brien, L., Maher, M., Shilton, N., McDonnell, K., \& Ward, S. (2001). Development of a DNA-based assay for species identification in meat and bone meal. Food Research International, 34, 409-414.

Dooley, J. J., Paine, K. E., Garrett, S. D., \& Brown, H. M. (2004). Detection of meat species using TaqMan real-time PCR assays. Meat Science, 68, 431-438.

Fajardo, V., González, I., Dooley, J., Garret, S., Brown, H. M., García, T., et al. (2009). Application of polymerase chain reaction-restriction fragment length polymorphism analysis and lab-on-a-chip capillary electrophoresis for the specific identification of game and domestic meats. Journal of the Science of Food and Agriculture, 89, 843-847.

Fajardo, V., González, I., López-Calleja, I., Martín, I., Rojas, M., García, et al. (2007). PCR identification of meats from chamois (Rupicapra rupicapra), Pyrenean ibex (Capra pyrenaica), and mouflon (Ovis ammon) targeting specific sequences from the mitochondrial D-loop region. Meat Science, 76, 644-652.

Fajardo, V., González, I., Martín, I., Rojas, M., García, T., \& Martín, R. (2010). A review of current PCR-based methodologies for the authentication of meats from game animal species. Trends in Food Science and Technology, 21, 408-421.

Fajardo, V., González, I., Martín, I., Rojas, M., Hernández, P., García, T., et al. (2008a). Real-time PCR for detection and quantification of red deer (Cervus elaphus) fallow deer (Dama dama), and roe deer (Capreolus capreolus) in meat mixtures. Meat Science, 79, 289-298.

Fajardo, V., González, I., Martín, I., Rojas, M., Hernández, P. E., García, T., et al. (2008b). Differentiation of European wild boar (Sus scrofa scrofa) and domestic swine (Sus scrofa domestica) meats by PCR analysis targeting the mitochondrial D-loop and the nuclear melanocortin receptor 1 (MC1R) genes. Meat Science, 78, 314-322.

Ghovvati, S., Nassiri, M. R., Mirhoseini, S. Z., Moussavi, A. H., \& Javadmanesh, A. (2009). Fraud identification in industrial meat products by multiplex PCR assay. Food Control, 20, 696-699.

Girish, P.S., Anjaneyulu, A. S. R., Viswas, K. N., Shivakumar, B.M., Anand, M., Patel, M., et al. (2005). Meat species identification by polymerase chain reaction-restriction fragment length polymorphism (PCR-RFLP) of mitochondrial 12S rRNA gene. Meat Science, 70, 107-112.

Hernandez-Chavez, J. F., Gonzalez-Cordova, A. F., Rodriguez-Ramirez, R., \& VallejoCordoba, B. (2011). Development of a polymerase chain reaction and capillary gel electrophoresis method for the detection of chicken or turkey meat in heat-treated pork meat mixtures. Analytica Chimica Acta, 708, 149-154.

La Neve, F., Civera, T., Mucci, N., \& Bottero, M. T. (2008). Authentication of meat from game and domestic species by SnaPshot minisequencing analysis. Meat Science, 80, 216-224.

Mafra, I., Ferreira, I. M. P. L. V. O., \& Oliveira, M. B. P. P. (2008). Food authentication by PCR-based methods. European Food Research and Technology, 227, 649-665.

Mafra, I., Silva, S. A., Moreira, E. J. M.O., Ferreira da Silva, C. S., \& Oliveira, M. B. P. P. (2008). Comparative study of DNA extraction methods for soybean derived food products. Food Control, 19, 1183-1190.

Martín, I., García, T., Fajardo, V., López-Calleja Hernández, P. E., González, I., et al. (2007) Species-specific PCR for the identification of ruminant species in feedstuffs. Meat Science, 75, 120-127.

Martín, I., García, T., Fajardo, V., Rojas, M., Pegels, N., Hernández, P. E., et al. (2009a). Polymerase chain reaction detection of rabbit DNA in food and animal feed. World Rabbit Science, 17, 27-34.

Martín, I., García, T., Fajardo, V., Rojas, M., Pegels, N., Hernández, P. E., et al. (2009b). SYBR-Green real-time PCR approach for the detection and quantification of pig DNA in feedstuffs. Meat Science, 82, 252-259. 
Matsunaga, T., Chikuni, K., Tanabe, R., Muroya, S., Shibata, K., Yamada, J., et al. (1999). A quick and simple method for the identification of meat species and meat products by PCR assay. Meat Science, 51, 143-148.

Ramalhosa, E., Magalhães, A. L., \& Pereira, E. L. (2012). Characterization of regiona Portuguese kitchens for Alheiras de Vinhais (PGI) production with respect to the processing conditions, final product quality and legal framing. Food Control, 26, 133-138.

Rodríguez, M.A., García, T., González, I., Hernández, P. E., \& Martín, R. (2005). TaqMan real-time PCR for the detection and quantification of pork in meat mixtures. Meat Science, 70, 113-120.

Rojas, M., González, I., Fajardo, V., Martín, I., Hernández, P. E., García, T., et al. (2009). Authentication of meats from quail (Coturnix coturnix), pheasant (Phasianus colchicus), partridge (Alectoris spp.), and guinea fowl (Numida meleagris) using polymerase chain reaction targeting specific sequences from the mitochondrial 12S rRNA gene. Food Control, 20, 896-902.

Rojas, M., González, I., Pavón, M.A., Pegels, N., Hernández, P. E., García, T., et al. (2011) Mitochondrial and nuclear markers for the authentication of partridge meat and the specific identification of red-legged partridge meat products by polymerase chain reaction. Poultry Science, 90, 211-222.

Rojas, M., González, I., Pavón, M.A., Pegels, N., Lago, A., Hernández, P. E., et al. (2010). Novel TaqMan real-time polymerase chain reaction assay for verifying the authenticity of meat and commercial meat products from game birds. Food Additives $\mathcal{E}$ Contaminants: Part A, 27, 749-763.

Santos, C. G., Melo, V. S., Amaral, J. S., Estevinho, L., Oliveira, M. B. P. P., \& Mafra, I. (2012). Identification of hare meat by a species-specific marker of mitochondrial origin. Meat Science, 90, 836-841.

Soares, S., Amaral, J. S., Mafra, I., \& Oliveira, M. B. P. P. (2010). Quantitative detection of pork's meat by duplex PCR. Meat Science, 85, 531-536.

Stamoulis, P., Stamatis, C., Sarafidou, T., \& Mamuris, Z. (2010). Development and application of molecular markers for poultry meat identification in food chain. Food Control, 21, 1061-1065.

Teletchea, F., Maudet, C., \& Hanni, C. (2005). Food and forensic molecular identification: Update and challenges. Trends in Biotechnology, 23, 359-366. 